\title{
FOREIGN TRADE LAW OF ROMANIA
}

\author{
GEORGE J. ROMAN"
}

\section{INTRODUCTION}

Romanian foreign trade with the free enterprise countries of Europe, the Americas, and Asia was insignificant for a long period after World War II. The main causes for this situation were the internal transformation taking place within Romania's social, economic and political structure, and the deep changes occurring in world politics and economics. Due to Romania's defeat, the lengthy presence of Soviet occupying forces, and her obligation to pay the Soviet Union in excess of \$300 million in war compensation, ${ }^{1}$ Romania has become a communist country whose entire economy, foreign affairs, and trade policies are molded in the Soviet pattern. The intense ideological struggle of international politics between the communist bloc and the free enterprise countries after World War II could not have had any favorable effect on the development of trade relations with Romania. The pre-war bilateral trade agreements (article ro of the Treaty of Peace between the Allied/Associated Powers and Romania) ${ }^{2}$ were reinstated by some of these countries but failed to become effective. Only in the I950's, when relations between the great powers were becoming more relaxed, did Romania begin to concentrate activity on the Western market. By this time, Romania had paid off war debts to the Soviet Union, as well as most compensation to the West for property nationalized in the late I940's.

In the period I955-59, the results of trade with the free market countries were modest. There were too many domestic problems; Romania lacked hard currency, commodities demanded by the free enterprise markets, qualified trading specialists, organization in domestic industry, and an effective export plan. Thus, in this period, total exports to the Western European countries amounted to \$80-9r.ro million and total imports to $\$ 51.80-65.90$ million. ${ }^{3}$ By 1965 , exports had risen to $\$ 266.55$ million and imports to $\$ 297.57$ million. ${ }^{4}$ This increase was due to the continuation of international détente, and to improvements in Romanian trade specialization and export output.

Between 1967 and 1972 , the Romanian government adopted a series of laws which totally reorganized both production and foreign trade on a competitive basis. The most important of these legislative measures were as follows: the 1967 decree establishing the Institute for the Study of International Economic Conjuncture; ${ }^{5}$ the

* Institute for International and Foreign Trade Law, Georgetown University.

1 Art. 22, Treaty of Peace with Romania, Feb. 10, 1947, 61 Stat. 1757, T.I.A.S. No. 1649 , 42 U.N.T.S. 3.

${ }^{3} I d$. art. xo.

${ }^{2}$ P. Marer, Soviet and East Europena Foreign Trade, i946-x964, at 230, 238 (1972).

II.

${ }^{8}$ Decree no. 907 of 1967 , Boletinul Oficial (Romanian Official Law Gazette) No. 35, Apr. $2 e$ 1967 [hereinafter cited as B.O.]. 
rg68 law establishing the Romanian Foreign Trade Bank; ${ }^{6}$ the r97I decree establishing the Romanian Association for Marketing (AROMAR) ${ }^{7}$ and the I97I law on foreign trade, economic, and technical-scientific cooperation activities in Romania. ${ }^{8}$ In the section entitled Foreign Trade Law several more important measures were passed, such as the r97r law on the organization and management of the socialist state enterprises; ${ }^{9}$ the 197 I decree on the authorization and working regulations of commercial agencies set up by foreign trading firms and economic organizations in Romania; ${ }^{10}$ and, more recently, the decree of 1972 on the constitution, organization, and function of mixed companies in the Socialist Republic of Romania. ${ }^{11} \mathrm{Ob}-$ viously, it is too early to evaluate the economic results of this domestic reform in the foreign trade field. But according to recent Romanian statistics, the value of total Romanian exports in I97I was about \$2,Ior million while total imports were approximately $\$ 2,103$ million, a deficit of $\$ 2$ million. ${ }^{12}$

Notwithstanding the optimistic trade statistics, the real economic situation within Romania is far from satisfactory. The President of the State Council of Romania recently noted that Romania's per capita income of $\$ 500$ to $\$ 600$ is but twenty to twenty-five per cent of that of the developed countries; that per capita production in basic industrial sectors is two to four times greater in developed nations; and that approximately forty-seven per cent of Romania's labor force work in agriculture, compared to ten to fifteen per cent in developed nations. ${ }^{13}$ But Romania is trying hard to develop trade with free enterprise countries and in the last five years these efforts have been successful. Today forty-five per cent of the value of her total foreign trade is with these countries while fifty-five per cent is with socialist countries. ${ }^{14}$

\section{I}

\section{Organization of Foreign Trade}

\section{A. The Communist Concept of Foreign Trade}

In Romania, the entire economic activity is carried out by state organs according to the political concept of the Romanian Communist Party. This rule is stated in the first article of the foreign trade law. ${ }^{15}$ Technically, a political concept contains two elements. The first is the political strategy in a certain matter. In our case that

\footnotetext{
${ }^{\circ}$ Law no. 16 of 1968, B.O. No. 80, June 22, I968.

${ }^{7}$ Decree no. I3I of I97x, B.O. No. 2I, Feb. I6, 197 I.

${ }^{8}$ Law no. I of 1971, I971 Colectia de hotariri si dizpozitil ale Consiliului de Ministri (Collection of Decrees of the Council of Ministers) No. I, at $x \geq 6$ [hereinafter cited as C.H.].

${ }^{\circ} \mathrm{Law}$ no. II of $197 x$, I97x C.H. No. 4 , at 68.

${ }^{10}$ Decree no. I5 of I97I, B.O. No. Io, Jan. 27, I971.

${ }^{11}$ Decree no. 424 of 1972 , B.O. No. 12I, Nov. 4, r97x.

12 Romantan Central Statistical Board, Statistical Yearbook of the Socialist Republic of Rosrania 417 (1972). The value is expressed in Romanian lei, calculated at five lei for one U.S. dollar.

${ }^{13}$ Report by N. Ceausescu, National Conference of the Romanian Communist Party, July 19-2I, 1972. ${ }^{14} I d$.

${ }^{15}$ Art. I, law no. I of 197I, I97I C.H. No. r, at I16. Article I provides: "The Socialist Republic of Romania carries on foreign trade in conformity with the Party and the State policy concerning expanded external economic relations ...."
} 
is foreign trade, which expresses the final purpose to be achieved through governmental activity over a long period of time. Today this political strategy seems to be the development over the next twenty years of a modern industrial sector by importing, on credits if possible, new Western technology, by encouraging Western industrial investment in the form of mixed Romanian foreign enterprises in Romania, and by favoring technical, economic, and scientific cooperation with other countries. The General Secretary of the Romanian Communist Party stated that by the end of this century it is expected that Romania will have become a multilateral developed country. ${ }^{16}$

The political-economic tactics is the second element of a political concept, and usually includes an arsenal of methods, political propaganda ideas, and practical means established by the Party, all of which have the purpose of achieving the political strategy. The Party and state organs, each in its field, are implementing these tactics in their relations with foreign partners. Thus, the idea of international trade and cooperation in economic, technical, and scientific matters is encouraged abroad by the diplomatic missions in other countries, Romanian delegations to international conferences and congresses, participation in international exhibitions and fairs, contacts and friendships with Western political, industrial, and financial personalities, publication of legal studies, and so forth. On the domestic level, among other tactical measures, the competent state organs adopt laws and take administrative measures aimed at achieving conditions favoring the realization of the political strategy of the Romanian Communist Party. Therefore, when article I of the foreign trade law emphasizes Romanian Communist Party power and control in that field, this means that the entire structure of that law, including the powers and the duties of each state body, is conceived to carry out the Party's political strategy.

\section{B. The Council of Ministers}

The Council of Ministers is the supreme body of administration in Romania, having under its jurisdiction the general direction of all executive activity. ${ }^{17}$ It is a collective body composed of all chiefs of departments (or ministries) and the leaders of the Romanian Trade Union and Youth Union, working under the direction of its President. ${ }^{18}$ According to law, the Council of Ministers has the task of organizing foreign trade activity by enacting necessary legislation and by authorizing the Romanian economic enterprises to carry out such activities as are needed. ${ }^{10}$ The Council is subordinated only to the State Council.

\section{The Ministry of Foreign Trade}

The new foreign trade law introduced two main changes in the older concept of doing business abroad: ( $\mathrm{I}$ ) decentralization of foreign trade activity in the sense

\footnotetext{
${ }^{18}$ Report by N. Ceausescu, supra note 13 , at $37-39$.

${ }^{17}$ Constitution of the Socialist Republic of Romania, art. 70, B.O. No. 22, Fcb. 20, 1968 [hereinafter cited as Constitution].

${ }^{18}$ Id. art. 73 .

${ }^{10}$ Art. 21, law no. 16 of 1968, B.O. No. 80, June 22, 1968.
} 
that the new law transfers the right to negotiate and conclude contracts from the foreign trade enterprises to the productive units, such as industrial centrals, enterprises, and plants, thus emphasizing the direct responsibility of these productive units for the fulfillment of their export-import plans; and (2) centralization of responsibility for day-to-day foreign trade activity within the Ministry of Foreign Trade. $^{20}$ Under the new law, the Minister of Foreign Trade has the following major responsibilities: ( $I$ ) to ensure the application of the laws, decrees, and decisions of the Council of Ministers in the field of foreign trade and to answer directly for the manner of implementation of the Council's plan; (2) to guide the activities carried on by economic units engaged in foreign trade, irrespective of their subordination, and to coordinate the level of prices of export or import products in foreign currency as practiced by these economic units; (3) to issue export and import licenses, control customs activity, and introduce restrictions on the import or export of goods to protect public health, national defense, or state security; (4) to study the foreign market, draw up surveys, and submit proposals to the concerned ministries and economic units; (5) to organize permanent economic representations abroad, guide and control their activity, and establish contacts with international economic bodies with the view of ensuring Romania's participation in such bodies; and (6) to ensure the expansion of foreign trade relations by the promotion of international economic and technical cooperation, conduct negotiations and conclude agreements, conventions, and protocols under the instruction of the Council of Ministers, and to answer for their implementation.

In addition to these exclusive powers, the law deals with situations in which the Minister of Foreign Trade acts in cooperation with other departments. The word "cooperation" in such cases means the duty of such departments to effect certain specialized activities which, due to their technicality, the Ministry of Foreign Trade could not manage. Thus the law provides that the Minister has the power to work out the international trade plan of economic and technical cooperation with the State Planning Committee, ${ }^{21}$ to work out the informational system in the foreign trade field with the Central Statistical Board, ${ }^{22}$ and so forth.

\section{Other State Economic Bodies}

The other ministries, central and local economic bodies, and those central cooperative and public organizations which are engaged directly or through their subordinate units in foreign trade have the duty to organize such activity within their administrative jurisdiction. The law provides that they are to guide, coordinate, and control their subordinated units in the production of quality goods which will be competitive in foreign markets. They work out proposals concerning the export-import plan as well as the proportions, structure, and orientation of future trade exchanges. They are responsible for the efficiency of imported in-

\footnotetext{
${ }^{30}$ Constitution, arts. 30,34

${ }^{21}$ Id, art. 34 .

${ }^{23}$ Id. art. 37 .
} 
stallations and the selection and training of the personnel employed by their subordinated units. When authorized to do so directly, or together with the Ministry of Foreign Trade, they may conduct negotiations and conclude agreements with foreign firms and ensure their implementation. They also coordinate participation in international fairs, exhibitions, and other forms of commercial propaganda and publicity. With the approval of the Ministry of Foreign Trade, these bodies organize the participation of their sectors in the permanent agencies abroad. ${ }^{23}$ The ministries and other central and local economic bodies engaged in foreign trade can organize within their framework separate departments, for example, general boards, offices, export-import departments, cooperation departments, and so on, depending on the volume and complexity of their assignments. ${ }^{24}$ Beginning in 197I, such foreign trade compartments were established particularly within the economic ministries and industrial centrals.

\section{E. The Romanian Foreign Trade Bank}

The Foreign Trade Bank was established in I 968 as a specialized unit of the External Operations Department of the Romanian National Bank for the purpose of carrying out Party and state policy in the field of payments, credits, and banking control of currency operations with foreign countries. ${ }^{25}$ The Bank works for fulfillment of the economic plan by directing the foreign currency operations resulting from trade between Romanian enterprises and their foreign trading partners. ${ }^{20}$

The Foreign Trade Bank has the primary function of facilitating trade by organizing in and outgoing payments with foreign enterprises, obtaining foreign and domestic credits, and concluding banking arrangements for the execution of governmental payment agreements, credit conventions, and other financial transactions. To this end, the Bank is empowered to provide currency exchange operations; to trade in foreign and domestic currency and trade bills; to provide credits in the required currency to Romanian trading enterprises; to authorize the export, import, and transfer of stocks; to issue drafts in favor of foreign payors and accept foreign drafts; and to endorse and guarantee foreign payment arrangements made abroad by or in favor of third parties.

The Bank may authorize other domestic organizations to effect exchange for their services or goods. In addition, the Bank keeps accounts for Romanian enterprises engaged in foreign trade and introduces banking controls on the use of their profits. ${ }^{27}$ The Foreign Trade Bank may participate in international organizations having a financial or banking character. It may engage in financial cooperation with other similar institutions in order to finance Romanian operations of economic and technical cooperation abroad. The Bank stands as a guarantor for the banking

\footnotetext{
${ }^{23}$ Id. art. 3 .

${ }^{24}$ Id. art. 33.

${ }^{25}$ Art. I, law no. I6 of r968, B.O. No. 80, June 22 , I968.

${ }^{28}$ Id. art. 3 .

${ }^{27}$ Id. art. 2.
} 
operations resulting from Romanian foreign trade enterprise activities. It has accounts in many banks in Europe, North and South America, Africa, Asia, and Australia as well as offices in England and other countries. The statutory fund of the Bank is 300 million lei (approximately $\$ 60$ million) and was paid by the Romanian government.

\section{F. Foreign Trade Activities Abroad}

In general the Romanian foreign trade activity in other countries is under the political responsibility of the head of the diplomatic mission in that country. The Ministries of Foreign Trade and Foreign Affairs organize permanent economic representation in other countries either through the economic sections of the diplomatic missions or in the form of trade offices, commercial bureaus or other forms in accordance with the conditions agreed upon with the authorities of the respective country. ${ }^{28}$ All of these trade units carry out their activity according to the rules and general directions given jointly by the Ministry of Foreign Affairs and the Ministry of Foreign Trade. ${ }^{29}$ This apparently is double subordination. In fact the law provides expressly that in case of specific foreign trade problems, these economic bodies have to act according to the instructions given them by the Ministry of Foreign Trade. ${ }^{30}$ Therefore there are no doubts that the powers of the head of the mission are limited to political issues, rather than the technical questions of foreign trade. The economic sections and offices of a diplomatic mission also contain general units, not specializing in trade, which are under the control of the Ministry of Foreign Affairs. These are in charge of surveying the general development of economic and political relations with the respective country. All other permanent or temporary economic representations-those of industrial centrals, foreign trade companies in which a Romanian enterprise is a partner, and the like-are subordinated to the head of the diplomatic mission. ${ }^{31}$ The laws dealing with this matter are obscure, giving the impression that a clear delineation of the powers of each department was not desired. ${ }^{32}$

The main task of the economic sections of the diplomatic missions, trade offices, commercial bureaus, and so on is to promote the continuous development of economic exchanges between Romania and the country in which they are located. To this end, they have the duel responsibilities of becoming acquainted with the economic and technical achievements of the country they are in and also to publicize the economic and technical-scientific achievements of Romania and the potential benefits of trade and cooperation. ${ }^{33}$ Another duty of these trade offices is to continuously investigate foreign markets and to promptly report to the

\footnotetext{
${ }^{28}$ Art. 49 , law no. I of $197 \mathrm{r}$, I971 C.H. No. I, at $x \times 6$.

${ }^{20}$ Id.

${ }^{s}$ Id.

${ }^{32}$ ld. art. 48,13 .

${ }^{33}$ Id. Compare art. 48, I2, with art. 49.

${ }^{33} \mathrm{Id}$. art. 50.
} 
Ministry of Foreign Trade on the data obtained, including their own conclusions and suggestions concerning the expansion of trade with that country. Finally, they have to study and make suggestions toward a better organization of the sale of Romanian goods in the respective country, always conscious of the policy of eliminating the intermediary trade agents in order to close the distance between the Romanian producer and the foreign consumer.

The foreign trade law provides for the right of certain Romanian industrial units-industrial centrals, foreign trade companies established with Romanian participation (mixed companies in foreign countries) and other economic organizations -to send permanent or temporary representatives to foreign countries. ${ }^{34}$ As mentioned above, these representatives carry out their activity under the guidance and control of the diplomatic missions. Their main function is the implementation of the export and import assignments of their units. They have to keep track of export and import contracts, contracts for services, and economic and technical cooperation under long-term contracts. They also have to solve any problems arising from the export of commodities or technical equipment. They must, for example, monitor the operation of machines and equipment during the guarantee period and ensure the necessary technical assistance, and organize a network for the sale of the products of the economic organization they represent. In the public relations area, these representatives are to establish direct contact with the management of foreign firms, to prospect the market with a view to increasing the volume and diversification of exports, to draw up surveys and analyses for the sectors and products they represent, and to ensure widespread publicity of achievements within those sectors as well as the export possibilities of those sectors.

II

\section{Foreign Trade Agreements}

The power to conclude international agreements on any matter lies with the Romanian government, which, according to the Romanian Constitution, has "the general leadership in the field of relations with other countries and takes measures for the conclusion of international agreements." ${ }^{35}$ This power is delegated to the ministries or to persons or delegations authorized to act on a certain matter. In the foreign trade field, the Ministry of Foreign Trade can be authorized to negotiate and conclude trade agreements. ${ }^{36}$ Consequently, the Ministry or the chief of a governmental delegation shall have authorization conferring the power to act (pleins pouwoirs) from the Romanian government to sign an international agreement. The ratification of such agreements is the responsibility of the Romanian National Assembly and, between its sessions, the responsibility of the Council of State-the superior body of state power in permanent session. Within the

\footnotetext{
${ }^{34}$ Id, art. 52 .

${ }^{36}$ Constitution, art. 70(3).

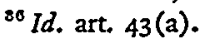


Council of State, ratification power lies with its President. Therefore, when a trade agreement provides its becoming effective immediately upon its signing, the Romanian pleins pouvoirs must be signed by the President of the Council of State with a notation of his consent to the immediate effects of that agreement.

Romanian trade agreements cover diverse subject matters because the notion of foreign trade activity within Romanian law is very broad. ${ }^{37}$ It includes foreign trade exchanges, economic, technical, and scientific cooperation, international transportation agreements of any kind, license and other industrial property, as well as financial agreements, tourism conventions, and so forth. This study is limited to the bilateral agreements concluded between Romania and free enterprise countries in the field of trade exchanges and in economic, technical, and scientific matters.

\section{A. Bilateral Trade Agreements}

The foreign trade agreement is designed to establish the legal framework within which the contracting governments promote the exchange of commodities between their countries. This exchange of goods is a complex operation, involving the right of persons and corporations of each state to act within the territory of the other state. Modern trade agreements evolved from pre-Twentieth Century instruments entitled "treaty of establishing, trade and navigation" or "treaty of friendship, trade and navigation." The title of such classical trade agreements expresses the matters regulated therein.

\section{Clauses of Establishment}

A foreign trade agreement is based on the belief that each nation will aid parties from the other nation in establishing commercial activities within its territory. This assumes the freedom of citizens of each state to establish businesses and to carry out commercial activities within the territory of the other state and to enjoy certain business privileges close, if not identical, to those which national businessmen or businessmen from other countries possess. These agreements also assume the right to transfer profits they have obtained to their home country. For reasons easy to understand, but hard to accept, such clauses, which aid the development of international trade, are no longer used in the trade agreements with East European countries. Almost all Romanian trade agreements omit these "clauses of establishment." The only recent trade agreement providing such a clause was concluded with India. Article 6 provides:

The persons and legal entities of each Contracting Party enjoy the most-favorednation treatment in regard to their personal protection and property protection when they are carrying out trade activities within the territory of the other Party. ${ }^{38}$

Romania has concluded trade agreements without establishment clauses with more than one hundred countries, including all developed industrial countries ex-

\footnotetext{
${ }^{37}$ Art. 3, law no. I of 197 I, 1971 C.H. No. I, at $x 16$.

${ }^{33}$ Trade and Payments Agreement Between Romania and India, Mar. 24, 197r, B.O. No. 54, May 3 , 1971.
} 
cept the United States. With the United States it has a limited special agreement concerning navigation. ${ }^{39}$

\section{Clauses Regarding Navigation}

Most of Romania's bilateral agreements include reciprocal clauses concerning vessels necessary for the transportation of commodities from one country to the other. However, several trade agreements do not contain such clauses, as, for example, the trade agreements with Australia, ${ }^{40}$ the Economic Union of Benelux, ${ }^{41}$ West Germany, ${ }^{42}$ Austria, ${ }^{43}$ Great Britain, ${ }^{44}$ Canada, ${ }^{45}$ Ecuador, ${ }^{46}$ Guinea, ${ }^{47}$ and Ghana. ${ }^{48}$

A typical navigation clause is found in article 3 of the trade agreement with Argentina, which states that " $[\mathrm{m}]$ erchant ships of each of the Contracting Parties shall enjoy, within the territory of the other, the most favorable treatment."40 With other countries, Romania has concluded special agreements concerning navigation in which, beside the most-favored-nation clause, there are agreements on related matters such as assistance for merchants in case of sea disaster or shipwreck, as well as double taxation. On this matter, article 6 of the agreement on navigation with Greece provides that

[t]he profit achieved by the merchant ships registered to one of the Contracting Parties from the international carriage [of commodities] will be exempted on the territory of the other Contracting Party from paying any kind of taxes or duties. ${ }^{50}$

Finally, other agreements provide that each party has the right, in case of carriage of goods by sea, to insure such goods with its national insurance companies. For example, article 9 of the trade agreement with Argentina provides:

The Government of the Argentine Republic reserves the right to have insured with Argentine companies goods of any kind which are exported to the Socialist Republic of Romania or imported from that country when the transport is at the seller's or the buyer's risk respectively. ${ }^{51}$

An identical clause is included in favor of Romania.

\footnotetext{
${ }^{39}$ Agreement with Romania, Dec. 3I, 1970, [1970] 3 U.S.T. 2727, T.I.A.S. No. 7017.

10 Trade Agreement Between Romania and Australia, May $18,1967,642$ U.N.T.S. 25.

${ }^{41}$ Trade Agreement Between Romania and the Economic Union of Benclux, Dec. 8, 1970, B.O. No. 16, Feb. $7,197 x$.

42 Trade Agreement Between Romania and the Federal Republic of Germany, Dec. 22, 1969, 1970 C.H. No. $I$, at $I x 6$.

${ }^{48}$ Trade Agreement Between Romania and Austria, Sept. 24, I970, 1970 C.H. No. 4, at 46.

"Trade Agreement Between Romania and the United Kingdom, Oct. 18, 1968, 1968 C.H. No. 4, at II9.

${ }^{4}$ Trade Agreement Between Romania and Canada, July I6, I97I, I97I C.H. No. 3, at 249.

${ }^{40}$ Trade Agreement Between Ecuador and Romania, Oct. 10, 1967, 642 U.N.T.S. 34.

47 Trade and Payments Agreement Between Romania and Guinea, Dec. x, x966, 642 U.N.T.S. 9o.

6 Trade Agreement Between Romania and Ghana, Nov. 23, 1966, 642 U.N.T.S. 64.

*0 Trade Agreement Between Argentina and Romania, Apr. 3, 1969, 709 U.N.T.S. 244.

${ }^{50}$ Agreement on Navigation Between Romania and Greece, Sept. 2, 1966, B.O. No. 86, July 3, 1968.

${ }^{51}$ Art. 9, Trade Agreement Between Argentina and Romania, Apr. 3, 1969, 709 U.N.T.S. 244.
} 


\section{Clauses Regarding Customs Duties}

Romania began trade activity with the free enterprise countries at a time when the political and economic attitude of the free market was not favorable to such action. The Western industrial countries, for political or economic reasons, were not impressed with what Romania offered in foreign trade. Even today they hesitate to conclude trade agreements with Romania on the most-favored-nation basis. In today's competitive international market, the refusal to grant such treatment constitutes a strong barrier to any trade activity. Few, if any, countries can take the risk of breaking the customs barrier even if they have a planned central economy which, in exceptional cases, can afford to trade on a planned loss basis.

Today, trade agreements concluded by Romania with Great Britain, ${ }^{52}$ West Germany, ${ }^{53}$ the United States, ${ }^{54}$ and the Economic Union of Benelux, ${ }^{55}$ do not include the most-favored-nation clause. In the agreement with Sweden, the parties have agreed to reciprocally grant "a treatment as much as possible favorable in problems concerning the trade."56 This, however, is not equivalent to a most-favored-nation clause. Article I of the trade agreement with the Republic of Senegal provides that "[i]n regard to the trade between the two countries, the Contracting Parties decide to mutually grant, as much as possible, an equal favorable treatment."57 This too falls short of a most-favored-nation treatment.

Yet, most Romanian trade agreements concluded with other countries include the most-favored-nation clause. This is true of agreements with Greece, ${ }^{58}$ India, ${ }^{59}$ Costa Rica, ${ }^{60}$ Ecuador, ${ }^{61}$ the United Arab Republic, ${ }^{62}$ Pakistan, ${ }^{63}$ Jordan, ${ }^{64}$ the Re-

\footnotetext{
52 Trade Agreement Between Romania and the United Kingdom, Oct. I8, I968, I968 C.H. No. 4, at 1 rg.

${ }^{63}$ Trade Agreement Between Romania and the Federal Republic of Germany, Dec. 22, I969, 1970 C.H. No. I, at II6.

${ }^{5}$ Agreement with Romania, Dec. 3r, 1970, [1970] 3 U.S.T. 2727, T.I.A.S. No. 7017.

EL Trade Agreement Between Romania and the Economic Union of Benelux, Dec. 8, 1970, B.O. No. I6, Feb. 7 , r97r.

5o Trade Agreement Between Romania and Sweden, Mar. 7, I967, B.O. No. 51, June 7, rg67.

67 Trade Agreement Between Romania and Senegal, Apr. 27, 1969, B.O. No. 75 (pt. I), July 5, 1969.

${ }^{68}$ Art. 4, Agreement on Commercial Exchanges Between Romania and Greece, Sept. I5, 1970, B.O. No. 20, Fcb. I2, I97I.

${ }^{60}$ Art. 3, Trade and Payments Agreement Between Romania and India, Mar. 24, r971, B.O. No. 54, May 3, 197r.

${ }^{\circ 0}$ Art. I, Trade Agreement Between Romania and Costa Rica, Nov. 3, I971, B.O. No. I40, Nov. 8, 197I.

${ }^{01}$ Art. I, Trade Agreement Between Ecuador and Romania, Oct. 10, 1967, 642 U.N.T.S. 34 .

${ }^{62}$ Art. 6, Trade Agreement Between Romania and the United Arab Republic, Nov. I4, I966, B.O. No. 38 , Apr. $26,1967,642$ U.N.T.S. 129.

${ }^{68}$ Art. I, Trade Agreement Between Romania and Pakistan, Apr. 6, I968, B.O. No. 72, June 5, I968.

"Trade Agreement Between Romania and Jordan, Nov. 22, 1968, B.O. No. 5 I (pt. 1), Apr. I2, I969.
} 
public of Niger, ${ }^{65}$ Mauritania, ${ }^{66}$ the Republic of Singapore, ${ }^{67}$ Guinea, ${ }^{68}$ Canada, ${ }^{60}$ Australia, ${ }^{70}$ and Spain. ${ }^{71}$ A typical most-favored-nation clause is found in article I of the trade agreement with Australia:

I. The Contracting Parties shall accord each other unconditional most-favorednation treatment in all matters with respect to customs duties and charges of any kind imposed on or in connection with importation or exportation of products and with respect to the method of levying such duties and charges, with respect to all rules and formalities connected with importation or exportation and with respect to all internal taxes or other internal charges of any kind.

....

4. Any advantage, favor, privilege, or immunity which has been or may hereafter be granted by either Contracting Party in regard to the matters referred to in paragraph I of the Article to any product originating in or consigned to any third country shall be immediately and unconditionally accorded to the like product originating in or consigned to the territory of the other party. ${ }^{72}$

Article 2 of the same agreement, completing the above text, provides:

r. No prohibitions or restrictions, whether in the form of quotas, import or export licenses, foreign exchange controls regulations, directives or any other measures, shall be instituted or maintained by either Contracting Party on the importation of any product from the territory of the other Contracting Party or on the exportation of any product consigned to the territory of the other Contracting Party, unless such prohibitions or restrictions are applicable to all third countries.

2. The provisions of paragraph I of this Article shall not apply to import of exchange prohibitions or restrictions applicable to all countries in like circumstances for the purpose of safeguarding the external financial position and balance of payments.

Almost all Romanian trade agreements provide certain situations when the most-favored-nation clause does not apply. Generally, these situations concern special advantages which each contracting party has previously granted to a third country and which it does not want to grant to the other party through the operation of the most-favored-nation clause. Therefore exceptions are placed on the coverage of the clause. For example, article 5 of the trade agreement with Australia provides that the requirements of articles $I$ and 2, concerning most-favored-nation treatment, shall not apply to "preferences or advantages granted by the Common-

\footnotetext{
${ }^{65}$ Art. 1, Trade Agreement Between Romania and Niger, May 5, 1967, B.O. No. 82, Scpt. 15, I967.

${ }^{86}$ Art. I, Trade Agreement Between Romania and Mauritania, Apr. I2, 1967, B.O. No. 82, Scpt. 15, 1967.

${ }^{\circ \tau}$ Art. I, Trade Agreement Between Romania and Singapore, Jan. 31, 1967, B.0. No. 36, Apr. 4, 1967.

${ }^{88}$ Art. I, Trade and Payments Agreement Between Romania and Guinea, Dec. I, x966, 642 U.N.T.S. 90.

${ }^{69}$ Arts. I, 2, Trade Agreement Between Romania and Canada, July 16, 1971, C.H. No. 3, at 249.

${ }^{70}$ Arts. I, 2, Trade Agreement Between Romania and Australia, May 18, I967, 642 U.N.T.S. 25.

${ }^{71}$ Art. 3, Agreement Between Romania and Spain on Trade Exchanges, Navigation, Transportation, and Cooperation, Apr. 21, I97x, B.O. No. 58, May 8, 197 I.

${ }^{72}$ Art. I, Trade Agrcement Between Romania and Australia, May I8, 1967, 642 U.N.T.S. 25.
} 
wealth of Australia within the framework of the Commonwealth of Nations or to Ireland." 73

In some trade agreements, the most-favored-nation treatment is reciprocally granted only under certain conditions. Article 6 of the commercial agreement with Spain provides that goods imported by each party cannot be exported without the approval of the other party, but can only be for the consumption of the importing party. ${ }^{74}$ Article 6 of the trade agreement with Ghana provides that:

Either Contracting Party shall obtain approval in writing from the other Contracting Party (which in the case of the Socialist Republic of Romania shall be the Ministry of Foreign Trade, and in the case of the Republic of Ghana the Ministry of Trade) before the resale or re-export of the commodities imported from the other Party to a third country. ${ }^{75}$

Other Romanian trade agreements utilize the GATT conventional system of tariffs. Thus, the commercial agreement with Spain specifies that the meaning of the most-favored-nation clause shall include a reference to the GATT system: "[t]hose principles shall be applied according to the dispositions of the General Agreement on Tariffs and Trade (GATT)." ${ }^{\text {"76 }}$ A similar solution is found in the agreement with Austria, which in article I provides that within the framework of trade exchanges between the two countries, Austria will apply the GATT conventional customs duties in force at the respective time and Romania will apply the lowest customs duties available at that time. ${ }^{77}$

Some agreements with developing countries-for example, those with Ghana and Guinea-provide a total reciprocal exemption from import duties and other charges for the following categories: ( $I$ ) samples of goods, if they are used only for obtaining orders for such goods and are not intended for sale; (2) catalogs, price lists, and prospectuses relating to commercial goods as well as items of goods for fairs and exhibitions, providing that they will not be sold; or (3) goods imported for repair, improvement, or processing, which will then be returned to the original country.

In addition, in some agreements the contracting parties emphasize their right to apply any kind of prohibition or restriction necessary for the protection of (I) their security interests; (2) public health or the prevention of diseases and pests in animals or plants; (3) the right to regulate the importation and exportation of arms, ammunitions, and other strategic materials; (4) public morality; and (5) national treasures of artistic, historic, or archeological value. They also reserve the right to restrict or prohibit the exportation, use, and consumption of nuclear mate-

\footnotetext{
${ }^{73}$ Id. art. 5 .

${ }^{71}$ Art. 3, Agreement Between Romania and Spain on Trade Exchanges, Navigation, Transportation, and Cooperation, Apr. 2I, 1971, B.O. No. 58, May 8, 1971.

${ }^{75}$ Trade Agreement Between Romania and Ghana, Nov. 23, 1966, 642 U.N.T.S. 64.

${ }^{70}$ Art. 3, Agreement Between Romania and Spain on Trade Exchanges, Navigation, Transportation, and Cooperation, Apr. 21, 1971, B.O. No. 58, May 8, I97r.

${ }^{77}$ Agreement Between Austria and Romania on Customs Duty, Feb. 28, 1968, 655 U.N.T.S. 132.
} 
rials, radioactive substances, or any other material which may be used in the development or production of nuclear energy.

\section{Schedules of Goods and Joint Commissions}

Almost every trade agreement has, in its annex, a schedule of goods for each contracting party, containing the items for which trade facilities will be provided. Some of the items are listed quantitatively with technical specifications, while for others no quantity is given. Since the trade agreements are generally concluded for a long period of time-three to five years-the initial schedule of commodities must be modified periodically. Thus trade agreements usually provide for the establishment of a joint commission, consisting of an equal number of representatives of each contracting party. This body is responsible for the supervision of the agreement and the revision of the schedule of commodities. The commission is usually a permanent body and may be called into session any time at the request of one of the contracting parties.

Those trade agreements which do not establish a joint commission usually make provisions for the contracting parties to consult whenever necessary or, in some cases, provide for an annual meeting of their representatives to examine the operation of the trade exchanges. ${ }^{78}$

\section{B. Economic, Technical, and Scientific Cooperation Agreements}

International cooperation in economic, technical, and scientific matters is a relatively new method used by the socialist countries for increasing the technological transfer from the more developed free enterprise countries. Romanian law provides for this kind of cooperation for the following reasons: (I) to intensify the participation of the Socialist Republic of Romania in the international division of labor; (2) to implement state plans concerning the growth of the national economy; (3) to improve and diversify the pattern of trade exchanges and enhance export efficiency; (4) to raise the technical quality level of production; and (5) to secure the participation of Romania in the development of other countries in economic, commercial, and financial domains. ${ }^{79}$

On the domestic level, international cooperation is divided under two jurisdictions. Economic and technical cooperation is coordinated by the Government Commission for Economic and Technical Collaboration and Cooperation and the Ministry of Foreign Trade. Scientific cooperation is coordinated mainly by the National Council of Scientific Research. It should be noted that at the 1972 National Conference of the Romanian Communist Party a Supreme Council of the National Economy was established; this body will probably have jurisdiction over all international cooperation in the future. ${ }^{80}$

\footnotetext{
${ }^{78}$ See, e.g., art. 3, Trade Agreement Between Romania and Canada, July 16, 1971, 1971 C.H. No. 3, at 249 .

${ }^{70}$ Art. 55 , law no. $\mathrm{I}$ of $197 \mathrm{r}, \mathrm{x} 97 \mathrm{r}$ C.H. No. $\mathrm{I}$, at Ir6.

${ }^{80}$ Report by N. Ceausescu, stupra note 13 .
} 
Romania has agreements on economic, technical, and scientific cooperation with all the industrially developed countries except the United States and with many developing countries. These include treaties with West Germany, ${ }^{81}$ Denmark, ${ }^{82}$ Italy, ${ }^{83}$ Tunisia, ${ }^{84}$ the Netherlands, ${ }^{85}$ the Somali Republic, ${ }^{86}$ the United Arab Republic, ${ }^{87}$ Spain, ${ }^{88}$ and India. ${ }^{89}$

These economic, technical, and scientific agreements constitute the legal framework within which interested organizations of each nation negotiate and execute contracts. The main obligation of the governments is to encourage their domestic organizations to engage in this type of cooperation. For example, in the agreement with West Germany, the contracting parties provide that they shall give particular attention to cooperation in the production of machinery, plants, and equipment entailing the manufacture of certain parts by each party. ${ }^{90}$ The agreement with France provides for cooperation between national enterprises of the two countries by studying methods to increase their respective production capacity and by prospecting third country markets. ${ }^{91}$ In the agreement with Italy, arrangements are made for the cooperation of the two countries' economic organizations in the preparation of projects, the construction and operation of new industrial installations, the expansion and modernization of older ones, and the training of personnel necessary for such industrial complexes. ${ }^{92}$ Also included are provisions for cooperation in the modernization and standardization of production techniques in preparation for joint projects in other countries as well as for joint use of patents, licenses, and technical documentation.

Virtually all agreements for technical and scientific cooperation include the establishment of a joint commission similar in structure and function to the commissions

\footnotetext{
${ }^{81}$ Agreement Between Romania and the Federal Republic of Germany on Technical and Economic Cooperation, Aug. 3, $x 967,642$ U.N.T.S. 54 .

${ }^{82}$ Agreement on Economic, Industrial and Technical Cooperation Between Denmark and Romania, Aug. 29, 1967, 656 U.N.T.S. 326.

${ }^{83}$ Accord Between Romania and Italy on Economic, Industrial and Technical Collaboration, Sept. 6, I965, 604 U.N.T.S. 50.

${ }^{84}$ Agreement on Scientific and Technical Cooperation Between Romania and Tunisia, Apr. 2I, I966, 604 U.N.T.S. 66.

${ }^{85}$ Agreement on Economic, Industrial and Technical Cooperation Between the Netherlands and Romania, July 20, 1967,646 U.N.T.S. 308.

${ }^{80}$ Agreement on Technical and Scientific Cooperation Between Romania and Somali, Apr. 20, Ig67, 642 U.N.T.S. 156.

${ }^{87}$ Protocol on Technical-Scientific Cooperation in Agriculture Between Romania and the United Arab Republic, Sept. 3, I966, 604 U.N.T.S. 74-

${ }^{88}$ Art. 3, Agreement Between Romania and Spain on Trade Exchanges, Navigation, Transportation, and Cooperation, Apr. 21, x97I, B.O. No. 58, May 8, I97I.

${ }^{80}$ Trade and Payments Agreement Between Romania and India, Mar. 24, I971, B.O. No. 54, May 3, I97I.

${ }^{00}$ Agreement Between Romania and the Federal Republic of Germany on Technical and Economic Cooperation, Aug. 3, I967, 642 U.N.T.S. 54 .

${ }^{01}$ Art. 3, Agrcement on Economic and Industrial Cooperation Between Romania and France, Feb. 2, I967.

${ }^{93}$ Art. 2, Accord Between Romania and Italy on Economic, Industrial and Technical Collaboration, Sept. 6 , 1965, 604 U.N.T.S. 50 .
} 
established in trade agreements. There are, however, variations such as the formation of a governmental joint commission in an agreement with France. ${ }^{03}$ This type of governmental commission has control over all joint commissions created by agreements between France and Romania on economic, scientific, and technical matters. Its main function is to encourage additional international cooperation in these fields.

\section{Agreements Concerning Finance and Credits}

The trade and cooperation agreements provide the means and the methods of payment for the commercial transactions or for the debts resulting from economic, technical, and scientific cooperation. The usual method of payments is the clearing operation. Typical examples are the trade and payments agreement with Guinea, the long-term payments agreement with Ghana, ${ }^{95}$ the trade and payments agreement with India, ${ }^{96}$ and the payments agreement with Greece. ${ }^{97}$ The Romanian Foreign Trade Bank opens clearing accounts for each country with which Romania has trade exchanges or international economic cooperation, while the foreign national banks open such accounts in favor of Romania. Payments between Romania and the other countries are effected through these accounts.

In order to ensure continuity of payments, Romania and the other contracting party usually provide in the agreement that their banks shall accord each other a non-interest bearing technical credit of a certain amount. If the debit account of either contracting party exceeds this amount, then that party is obliged to cover the difference by deliveries of goods within a certain period of time. If at the end of this period the debt balance still exceeds the amount provided as technical credit, then the debtor party, at the request of the creditor party, shall cover the difference by a transfer in freely convertible currency. Most agreements providing for payment in freely convertible currency also specify the parity of this currency at the time of the execution of the agreement in dollars and in fine gold-for example, $\$ 1.00$ $=0.88867 \mathrm{r}$ grams of fine gold. In case of a change in parity, the agreements provide that the banks are to adjust the above mentioned debt balance in proportion to the change in parity, so that the gold value of the balance and the technical credit remain unchanged. Similar adjustments are made in case of non-liquidated value in contracts concluded between Romanian enterprises and foreign corporations acting within the framework of a trade agreement.

\footnotetext{
${ }^{93}$ Agreement Between Romania and France on the Governmental Romanian-French Commission, Jan. $x 7$, 1969, 1970 C.H. No. $x$, at 183 .

'Arts. 9-1r, Trade and Payments Agreement Between Romania and Guinea, Dec. I, 1966, 642 U.N.T.S. 90 .

${ }^{\circ 5}$ Payments Agreement Between Romania and Ghana, Nov. 23, 1966, 642 U.N.T.S. 80.

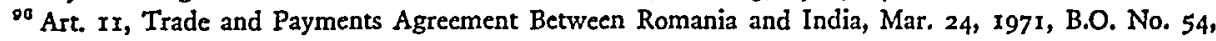
May 3, $197 x$.

${ }^{87}$ Art. 2, Payments Agreement Between Romania and Grecee, Dec. 15, 1970, B.O. No. 20, Feb. 12, I971.
} 
III

\section{INTERnal Foreign Trade Organizations}

Before the adoption of the new foreign trade law, Romanian commercial exchanges were carried out almost exclusively by the specialized foreign trade enterprises. 'The reform brought by the new law is designed to decentralize foreign trade. Thus it provides that foreign trade may be carried out directly by the following economic units: ( $\mathrm{x}$ ) industrial centrals or other productive units having such status; (2) units supplying services or executing work in foreign countries or in Romania for foreign interests; and (3) specialized foreign trade enterprises. ${ }^{98} \mathrm{Be}$ side these economic units, the law also provides that any other Romanian productive unit is presumed to handle its own foreign trade activities directly and, consequently, is answerable for them, even if it in fact has no direct relationships with the foreign market. ${ }^{99}$

Apparently the law brings small productive units closer to the foreign market to make them directly responsible for the fulfillment of that part of their economic plan which concerns the production of certain commodities intended to be exported. Thus, if the economic plan of a small productive unit assigns to it the task of manufacturing a certain part to be delivered to a large industrial central for installation in a complex machine intended for export, that small productive unit is legally considered to be directly handling foreign trade and is answerable as such for nonfulfillment. Even if the total output of goods called for by its economic plan is quantitatively overfulfilled, if it did not deliver those commodities or, when delivered they were refused by the foreign partner as unacceptable, the economic plan of such a productive unit is considered unfilled in toto because "[f]or productive units, delivery of the exportable products is considered to have been made if the goods have been taken delivery of in keeping with legal regulations."100 Moreover, " $[t]$ he production cycle is considered to have been concluded when the output has been sold and payment for it has been made."101 Since each productive unit knows that a refusal of its commodities for quality reasons results in nonfulfillment of its economic plan, the unit is obliged to keep up to date with the foreign market quality standards and to adjust its export production accordingly.

\section{A. Industrial Centrals}

Under the broader name "economic units carrying out foreign trade activities," the law includes the first two types of units mentioned above-the industrial centrals or other productive units having such a status, and the units supplying services or executing work in foreign countries or in Romania for foreign partners. ${ }^{102}$ For both types of units article 22 provides the same main functions:

\footnotetext{
${ }^{98}$ Art. 7 , I I, law no. I of I97I, I97I C.H. No. I, at II6.

${ }^{\circ}$ Id. 92.

${ }^{100} \mathrm{Id}$. art. 8, I 4 .

${ }^{101}$ Id. I 2 .

102 Id. art. 22.
} 
(a) to elaborate the export-import plan in accordance with their own surveys and investigations of the foreign market as well as to fulfill the contracts they have executed with foreign partners;

(b) to implement their export-import assignments and the receipts and payments plan in foreign currency, to execute contracts with foreign partners or to participate in the execution of such contracts by the units authorized to carry out foreign trade activities;

(c) to organize export production and to develop new products with higher technical and economic features;

(d) to get the most advantageous sale of goods in the foreign market and to increase export efficiency by ensuring the competitiveness and high quality of goods, suitable conditions of display, packing and delivery, as well as other conditions which may influence the price obtained in the foreign market;

(e) to arrange for design and construction of machines, tools, assembly work, and services in foreign countries in order to improve price, time of delivery, and economic efficiency;

(f) to fulfill their contractual obligations with foreign partners and to take advantage of rights arising from these contracts;

(g) to attain the technical and economic skills necessary for the operation;

(h) to provide a careful management and use of raw materials, auxiliary materials, and other imported goods;

(i) to participate in fairs and exhibitions abroad, construct in due time exhibits and displays, organize commercial advertising, and provide the commercial publicity, material, catalogs, prospectuses, and other materials for the products included in their export schedules;

(j) to organize warehouses and shops for the display and sale of products abroad;

(k) to send permanent or temporary delegates to foreign countries and to establish other forms of representation abroad;

(l) to ensure the supply of imported products to the subordinated units within the framework of their import plan;

(m) to organize, according to the regulations in force, cooperation with foreign firms and organizations in production for domestic markets as well as for export needs and to conclude necessary contracts; and

(n) to select and train the personnel needed for foreign trade activity.

The industrial centrals represent a new form of industrial organization conceived by the law of $197 \mathrm{x} .{ }^{103}$ They were established by grouping identical or related industrial units under a single management, resulting in a concentration or merger of enterprises with the aim of increasing their industrial power. As the socialist system does not include antitrust legislation, these units apparently are free from competition both in the domestic and foreign markets.

${ }^{108}$ Law no. II of 197I, I97I C.H. No. 4, at 68. 
Romanian production is organized into four basic units: the ministry, the central industrial office, the producing enterprise, and the plant. The functions of each of these units is illustrated in the following table. ${ }^{104}$

\section{InDUSTRIAL Unit}

Economic Ministry

Central Industrial Office

Enterprise

Plant

\section{Description}

Encompasses planning and operation of an entire industry

Sub-unit of ministry based on groupings of similar enterprises

$$
\begin{aligned}
& \text { Sub-unit of Central } \\
& \text { Industrial Office } \\
& \text { (similar to a large } \\
& \text { U.S. corporation) }
\end{aligned}
$$

\author{
Activity \\ Draws up industry planning \\ directives and coordinates \\ them with political priorities \\ Functions as the profit \\ center with individual pro- \\ duction goods, procurement \\ rights, and accounting procedures \\ Manages production and \\ marketing of certain kinds \\ of goods \\ Produces goods
}

Each industrial central has a specalized compartment for export-import. This unit is designated a department, office or service of export-import. A compartment has the right to represent the industrial central in its relations with foreign parties and to negotiate and conclude foreign trade contracts. Its duty is to implement the industrial central's export-import plan. ${ }^{105}$ To this end, each specialized compartment has an open account in foreign currency with the Romanian National Bank to receive the necessary credits. The profit obtained from the transactions of a compartment is annually transferred to the industrial central. ${ }^{106}$ As part of the industrial central, the export-import department does not enter into any contractual relation with the enterprises or plants which belong to the same industrial central, but it has to consult them regarding quality, quantity, price, terms of delivery, and so forth before it makes offers, accepts orders of delivery, or signs contracts for commodities manufactured by those enterprises or plants. ${ }^{107}$

In I97x, foreign trade enterprises were organized, some of which are subordinated to one or more industrial centrals and some of which are specialized foreign trade enterprises, under the control of one or two ministries or central state bodies. The foreign trade enterprise subordinated to one or more industrial centrals exists as a separate legal entity, apart from the industrial central. It has its own open account with the Romanian Foreign Trade Bank and retains any profits earned. ${ }^{108}$ Therefore, every subordinated foreign trade enterprise must each year

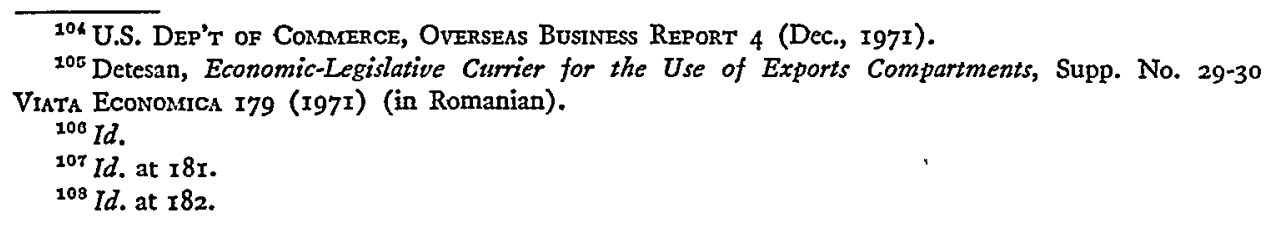


contract with its industrial central for the sale of those commodities which cannot be sold directly by the industrial central's department of export-import. This type of contract is similar, but not identical, to commission contracts as they are known in European commercial codes. ${ }^{109}$ In essence such a contract provides for the obligation of the subordinated foreign trade enterprise, in exchange for a specified commission, to find a buyer for a specified type and volume of industrial central commodities, at a specified price, and to facilitate the conclusion of a contract of sale between a representative of the industrial central and the foreign buyer. Under the terms of such contracts, the foreign trade enterprise is not buying the commodities from the industrial central but is only acting as an agent of the industrial central. As a consequence, the industrial central continues to be the owner of the commodities until the foreign sale is complete, and thus it bears the entire risk of loss. The contract also includes provisions concerning the liability of both parties in case of non-performance, including penalties. In addition, it contains all the contractual conditions and technical specifications of commodities which the industrial central wants to be accepted by the foreign partner.

Examples of foreign trade enterprises subordinated to industrial centrals include the following: ( $\mathrm{I}$ ) the foreign trade enterprise Autotractor (Brasov), subordinated to the Motor and Tractor Industrial Central (Brasov); (2) the intercentral foreign trade enterprise Masinexport, subordinated to the Machine-Tool Industrial Central and also to the Fine Mechanics, Optics and Instruments Industrial Central (Bucharest); (3) the intercentral foreign trade enterprise Electronum, subordinated to the Electronic and Vacuum Technique Industrial Central and also to the Automatization Industrial Central (Bucharest); and (4) the intercentral foreign trade enterprise Technoimport, subordinated to the Fine Mechanics and Aeronautics Industrial Central (Bucharest) as well as to the Group of Ballbearing Manufacturing Works (Brasov).

\section{B. Specialized Foreign Trade Enterprises}

The specialized foreign trade enterprise is intended to serve all industrial and economic units except the industrial centrals which have their own subordinated foreign trade enterprises. The specialized enterprises are, in each field of activity, subordinated to the respective ministries and central state bodies. They have the right to enter into domestic contracts with any industrial or economic unit or with the industrial centrals if this is necessary.

The various functions of the specialized foreign trade enterprises are enumerated in article 24 of the foreign trade law. ${ }^{110}$ They are expected to fulfill their export plans while obtaining the best price possible in the foreign market and meeting the standards of quality and terms demanded by the foreign buyers. Specialized foreign

\footnotetext{
${ }^{100}$ Art. 24 , law no. I of 1971 , I97x C.H. No. $\mathrm{r}$, at $\mathrm{r} 16$.

${ }^{110} \mathrm{Id}$.
} 
trade enterprises also negotiate and conclude contracts with foreign partners at the most advantageous price and on payment terms in conformity with the interests of the productive unit. They are expected to investigate the foreign market and to inform the productive units about the price-level and trends in that market in relation to the products manufactured by those units. In addition, they are to advise the productive units in the adjustment of their production to meet the demands of the foreign market, with the view of ensuring the most efficient use of material resources and labor. The specialized foreign trade enterprises also have many of the powers the law gives to the "economic units carrying out foreign trade activities."111

There are three basic types of contractual arrangements between the specialized foreign trade enterprises and the industrial or economic units.

\section{r. Contracts Based on Commission}

The plan of a specialized foreign trade enterprise subordinated to a ministry or central state body usually contains a provision for everything which the industrial and economic units subordinated to such ministry have to export or import. Since both the specialized foreign trade enterprise's plan and the plan of each industrial or economic unit are parts of the national economic plan of Romania, they are obliged by law to enter into a contract based on commission. For the specialized foreign trade enterprise, as a separate legal entity, this is the only way to make a profit, since it is a commercial, not a productive, enterprise.

The contract concluded with the industrial and economic units is the same as that concluded between an industrial central and its subordinated foreign trade enterprise. The obligation of the specialized foreign trade enterprise is to find a foreign buyer for the commodities the industrial unit wants to sell or, conversely, to find a supplier for the commodities the industry needs. In each of these situations the commission contract provides in detail the legal framework and terms of the contract the industrial or economic unit wants to conclude with the foreign partner. In addition, the contract on commission delineates the powers with which the specialized foreign trade enterprise is authorized to act. Thus the contract will indicate whether the enterprise is to study the foreign market alone or with the industrial unit's assistance and how it is to negotiate its arrangements. For these services, should a sale be arranged, the domestic industrial unit has to pay the specialized foreign trade enterprise a commission in an amount provided by domestic regulations. The contract on commission basis is fulfilled only when the industrial unit or the enterprise, acting with delegated power, has signed the contract with the foreign interest.

Disputes arising from contracts on commission basis are usually settled by the economic arbitration commission of the ministry to which the parties are sub-

\footnotetext{
${ }^{111}$ ld.
} 
ordinated. When the parties are subordinated to different ministries or central state bodies, disputes are settled by interdepartmental arbitration. ${ }^{112}$

Examples of specialized foreign trade enterprises subordinated to ministries or central economic bodies are the following: Industrial Import, subordinated to the Machine-Tool Ministry and the Metalworking Industry Ministry; Mechanoexport, subordinated to the Machine-Tool Ministry; and Romchim and Petrolexport, both subordinated to the Chemical Industry Ministry.

\section{Contracts Based on Trade Discount}

This type of contract is used by the specialized foreign trade enterprises for the purpose of selling in foreign markets certain domestic goods which either were not included in their export plan or were surplus goods which could not be sold through the contract on commission basis. The contract usually provides that the price of goods at export shall include the production price plus export expenses including the cost of transportation to the Romanian frontier plus an amount representing the specialized foreign trade enterprise's trade discount for the sale of the goods abroad. It also contains general clauses concerning terms of delivery, means of transportation, the quality and quantity of goods, payments, and so forth. ${ }^{113}$ The main difference between this type of contract and one based on commission is that in trade discount contracts the enterprise is acting in its own name and assuming the risks itself.

\section{Contracts for the Sale of Goods}

The foreign trade law also gives specialized foreign trade enterprises the right to buy goods from domestic economic units and to sell them to foreign interests on a profit basis. ${ }^{114}$ Such goods are usually supplied by the agricultural or professional cooperatives. The specialized foreign trade enterprises sometimes pack, sort, or otherwise modify the goods to meet foreign market demands. The operation of this type of contract is governed by domestic rules. The specialized foreign trade enterprises act on the foreign market as the owners of these goods and personally assume all the risks.

Although the law does not specify which enterprises can engage in such contracts, only a few of them, particularly those specializing in the sale of agricultural goods or those in very specialized fields, are doing business in this manner. Examples include: (I) the foreign trade enterprise Agroexport in Bucharest, which exports meat, meat conserves, tobacco, and the like; (2) Fructexport in Bucharest, which exports vegetables, fruits, fruit conserves, and wine; (3) Mercur, also in Bucharest, which handles the sale of goods manufactured for domestic consumers; and (4) Exincoop and Icecoop, which export goods and commodities manufactured by different productive cooperative units and intended for large consumption.

\footnotetext{
${ }^{112}$ Detesan, supra note 105, at $\mathrm{x} 86$.

${ }^{113}$ Id. at 194 .

114 Art. 24, law no. I of I97I, I97I C.H. No. I, at II6.
} 


\section{IV}

\section{Joint Ventures with Free Enterprise Countries}

When Romania enters into an international agreement for economic, scientific, or technical cooperation, the rights and obligations of Romania are delegated to a subordinate economic organization, generally an industrial central or a specialized foreign trade enterprise.115 In I97x Romania had agreements with sixty countries of which thirteen were with socialist, fourteen were with developed, and thirtythree were with developing countries. There were almost two hundred contracts for international cooperation signed between 1967 and 1971. The foreign trade law provides for two methods of international cooperation, joint ventures between Romanian enterprises and foreign firms, or mixed companies established in Romania or in other countries. ${ }^{110}$

\section{A. Joint Ventures}

The joint venture is one of the favorite methods of organization in Romania, although not the most efficient. In a joint venture each partner, the Romanian enterprise and the foreign corporation, keeps its own separate legal identity and executes certain work as provided by contract.

With developed nations, joint ventures mostly consist of the supply and installation of plants and equipment in Romania by the foreign partner. These operations utilize a long-term credit and licensing contract between the Romanian enterprise and the foreign corporation, previously approved by their governments. The contract states the obligations of each partner in the joint effort to achieve the desired goal. The contracts differ in the method of payment of the long-term credit. Some provide for payment out of the eventual production of the plant being constructed, some by delivery of other goods, and still others by transfer of a combination of goods and currency.

During the last five-year Romanian economic plan, between I966 and r970, foreign corporations participated in approximately $5_{50}$ facilities and supplied over \$I billion in completed plants and equipment. ${ }^{117}$ These included the construction of an automobile plant in Pitesti, for the manufacture of the Romanian automobile, Dacia IIO, in cooperation with the French auto manufacturer Renault; ${ }^{118}$ cooperation with English firms in the production of airplanes and electrical transformers for locomotives; $;^{119}$ and cooperation with Japanese corporations in building Romanian plants for the production of dolomitic blocks, aluminum wire-drawing and

\footnotetext{
${ }^{115}$ Detesan, supra note I05, at 359 .

${ }^{110}$ Arts. 57, 58, law no. I of $297 \mathrm{r}$, 197r C.H. No. $\mathrm{x}$, at rr6.

${ }^{112}$ U.S. DEP'T OF COMMERCE, supra note 104, at I6.

${ }^{118}$ L'Exposition des Réalisations de l'économic nationale de la Républiquse Solisliste de Roumanie, I969 COMMERCE ExTERIEUR No. 3(72), at 33 [hereinafter cited as L'Exposition].

${ }^{110}$ Detesan, supra note I05, at 365 .
} 
cabling, and equipment for steel pipes and scaled iron sheets. ${ }^{120}$ In addition, a joint venture with the West German firm Wedag plans to export modern cement plants to developing nations. Other joint ventures are with interests in Italy, Iran, Syria, India, and Venezuela. ${ }^{121}$ In the five-year economic plan for 1971 to r975, Romania is seeking foreign participation in the construction of twenty-seven complete plants in the fields of food processing, light industry, oil, mining, geology, metal-working, chemicals, and machine building. ${ }^{122}$

In order to facilitate joint ventures, the Romanian government has adopted a special law which allows the foreign firms to set up their own agencies in Romania, ${ }^{123}$ or to be represented by specialized Romanian economic organizations $^{124}$ on the condition that the Romanian economic organization will have the same right in the other country. ${ }^{125}$ The authorization for the establishment of a foreign trade firm's agency in Romania is given by the Ministry of Foreign Trade, with the approval of the Council of Ministers. Once established, these trade agencies are allowed to work with the partner Romanian economic organization to establish commercial operation by negotiating contracts, making market and advertising studies, obtaining technical assistance for equipment, transporting goods, and other similar economic activities. ${ }^{128}$

The agencies of foreign trading firms have bank accounts in foreign currency with the Romanian Foreign Trade Bank through which they are required to transact all financial activity, including the payment of their income tax. ${ }^{127}$ The law also provides that the foreign firms and economic organizations are responsible for the deeds and activities of their agencies. ${ }^{128}$ Since the agencies of foreign trading firms are acting under Romanian law, their personnel are entitled to represent the foreign interest before Romanian legal bodies and arbitration commissions. ${ }^{120}$

The authorization of an agency can be withdrawn by the Ministry of Foreign Trade with the approval of the Council of Ministers for infringement of Romanian laws by the personnel of the agency, for exceeding the limits of the activity specified in the authorization, or when the reciprocal rights of the Romanian partner are suspended by the foreign country. ${ }^{130}$

Romanian and foreign citizens having their domicile in Romania may be employed by the agencies of foreign trade firms only through the Romanian Chamber of Commerce, on a contractual basis. The law provides that the foreign firm must

\footnotetext{
${ }^{220}$ Alexa, The Development of Romanian-Iapanese Economic Relations, 4 VIATA Economica 7 (197x) (in Romanian).

${ }^{121}$ L'Exposition, supra note rr8.

122 U.S. DEP'T OF COMMERCE, supra note 104, at 22.

${ }^{123}$ Decree no. 15 of 197 r, B.O. No. 10, Jan. 27 , 1971.

${ }^{124}$ Id. art. I.

${ }^{225} I d$. art. 2.

${ }^{128}$ Id. art. 4 .

${ }^{127}$ Id. arts. 15, I7.

${ }^{128}$ Id. art. 3.

${ }^{120}$ Id. arts. II, 12.

${ }^{130} \mathrm{Yd}$. art. 19.
} 
pay for these services in foreign currency, the amount to be set by the service contract. Out of this sum the staff will be paid, and the required social contributions will be made. ${ }^{131}$

\section{B. Mixed Companies}

The device of mixed companies was adopted in Romania in November, 1972 , as another means of accelerating the country's industrialization. There is a major difference between the legal status of joint ventures and that of mixed companies. In the joint venture each partner keeps its distinctive legal identity, acting for its own profit and risk, while in the case of a mixed company the partners establish a new legal entity, which, once set up, acts under its own name, for its own profit, and on its own risk totally separate from the founders' partners. Therefore, from the standpoint of a foreign firm, the mixed company is primarily a long-term investment rather than an expansion of that firm's organization.

Romanian law ${ }^{132}$ allows for establishment of mixed companies in Romania in industry, agriculture, building, tourism, transport, scientific and technological research work, and other related fields. ${ }^{133}$ Prior to the establishment of a mixed company, approval is required in the form of a decree from the Romanian State Council at the recommendation of the Council of Ministers. Once established, the mixed company must register with the Ministries of Foreign Trade and Finance. ${ }^{134}$ Before granting approval, the governmental bodies are required to consider whether the proposed mixed company would contribute to the development of the national economy by activities such as promoting exports, expanding markets, diversifying goods for export, furthering scientific research and advanced managerial methods, or by training specialists. These factors indicate that Romania anticipates that mixed companies will concentrate on foreign trade rather than domestic consumption.

The mixed companies are established as Romanian legal entities and operate according to the laws of Romania. They have the status of a joint-stock or limited liability company in which the Romanian share shall not be less than fifty-one per cent. ${ }^{135}$ The Romanian partner in a mixed company may be one or more economic organizations, industrial centrals or other economic units authorized to participate in foreign trade. The foreign partner may be one or more organizations, companies or individuals. ${ }^{136}$

The foreign partner's contribution to the mixed company may be financial, assets required for operation, or assignment of industrial rights. The contribution of the Romanian partner may include the right to use land for the location of the com-

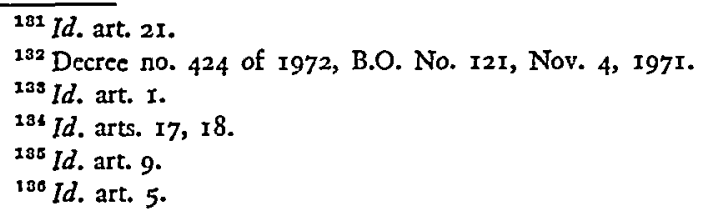


pany: If the value of the right of land utilization is not included in the Romanian partner's contribution, the mixed company must pay rent to the Romanian state for the use of that land. ${ }^{137}$ The partners agree to convert their contributions into a certain currency and the assets of each partner are always evaluated in that currency.

The Romanian state guarantees the foreign partner the right to transfer abroad the profits and the value of contributions resulting from distribution of the credit balance upon liquidation, but only after payment of taxes, dues, and contributions to social insurance is made and after all legal and contractual obligations of the mixed company are fulfilled.

A mixed company is organized according to Romanian law and the company's own charter, bylaws and memoranda. These instruments include the names of the partners, the juridical form and name of the company, the purpose of the company, the location of its headquarters, the distribution of shares, the duration of the organization, and the rights and duties of the partners and the managing bodies. The charter provides for the distribution of profits, the manner of settling disputes between partners, and for the appointment of personnel and their remuneration. The charter also specifies in detail the method of managing the organization. Usually, there is a general assembly of the mixed company, an administrative council or managing committee, and individual directors. ${ }^{138}$ The general assembly is required by law to include two delegates appointed by the Ministry of Finance. ${ }^{130}$

Each mixed company is required by law to draw up annual and five-year plans for economic and financial activities, to be approved by its managing bodies. ${ }^{140}$ Since the Romanian partner always has a majority interest, it is assumed that these plans will, for all practical purposes, be parallel to the overall Romanian plans.

The company may buy raw materials and other commodities in a competitive manner from either Romania or other countries and may sell its products in the same manner. The sale of commodities to a foreign market may be effected either directly or through a Romanian foreign trade enterprise. ${ }^{141}$

The accounts of a mixed company are kept in the currency the partners have agreed to in their charter. ${ }^{142}$ The amortization of a company's assets, considered by Romanian law as fixed assets, is included in the cost of production until such assets are amortized. But the amortization period cannot be longer than the legal life of the mixed company. ${ }^{143}$ From its annual profits, the company establishes a reserve fund. After all operations are complete and taxes paid, the net profits of the company are distributed to the partners or reinvested in the company, according to its

\footnotetext{
${ }^{137}$ Id. art. I4.

${ }^{188}$ Id. art. Io.

${ }^{189}$ Id. art. $3 x$.

${ }^{140} I d$. art. 3.

${ }^{141} I d$. arts. 22, 23.

${ }^{142}$ Id. art. 25.

${ }^{143}$ Id. art. 27.
} 
needs. The profit distributed to the partners is in proportion to their share of ownership. ${ }^{144}$

For everyday activities, the law requires the mixed companies to open accounts with Romanian banks in both foreign and Romanian currencies. The transfer from one account to another is at the established exchange rate for non-commercial operations. ${ }^{145}$ At the request of either partner, the company's executive bodies are to present statements showing the activity of the company, its assets and liabilities, and its profits and losses. ${ }^{146}$

It is too early to evaluate the legal and economic effects of mixed companies on Romanian foreign trade. Thus far, only two mixed companies have been established in Romania, both with Japanese participation. One of them produces synthetic fibers, the other fodder concentrates. ${ }^{147}$

Mixed companies with Romanian participation have been established in several free enterprise nations. Many are designed to promote the sale of Romanianproduced goods. Examples include Vitama, for the sale of Romanian equipment; Romital, for the sale of chemical products; and Torimpex. ${ }^{148}$ All are located in Italy. Also, Arcomar has been established in Morocco, ${ }^{149}$ Arcode in Great Britain, Decofra in France, and Countechimie in West Germany. ${ }^{150}$

\section{$\mathrm{V}$}

\section{The Planning of Foreign Trade}

Romania's economy is based on five-year plans. Each economic five-year plan is divided by year, semesters, and trimesters. Each of these subdivisions is further divided according to the economic unit which will be responsible for its implementation. The foreign trade plan is divided into the following areas: ( $\mathrm{I}$ ) export of commodities; (2) import of commodities; (3) import contracts for acquisition of industrial equipment and plants; and (4) a special foreign payments plan, which includes payments resulting from the transactions provided by the above three special plans. ${ }^{151}$

Article ${ }_{7} 7$ of the foreign trade law provides that each economic unit engaging in foreign trade must prepare a draft plan for that unit, based on investigative surveys of its markets. The proposed plans from each of the subordinated units are then coordinated by the industrial centrals and passed on to the respective ministry. Each ministry then prepares a draft plan based on the plans submitted by the industrial centrals and subordinated foreign trade enterprises. The draft plans of

\footnotetext{
${ }^{144} I d$. art. 26.

1st Id, art. 28 .

${ }^{140} I d$. art. 30.

${ }^{167} 24$ U.N. ECON. BULI. FOR EURORE 43.

${ }^{248}$ Albu \& Puin, The Trade with Italy, Ix VIATA Economica 6 (197I) (in Romanian).

${ }^{140}$ Cioran, Romanian Constructors Abroad, 33 VIata Economica 8, I8 (1972) (in Romanian).

${ }^{160} L ' E x p o s i t i o n$, supra note $\mathrm{I} \mathrm{r} 8$, at 35 .

${ }^{161}$ Detesan, supra note I05, at I5I.
} 
each ministry and other central state bodies are submitted to the State Planning Committee, where they are revised and organized into a comprehensive national draft plan for foreign trade. This is then combined with the domestic draft plan to produce the draft plan for the entire economy. This national economic five-year plan is submitted to the Council of Ministers and by it, with a bill recommending approval, to the Romanian National Assembly. Once approved by the National Assembly, the plan becomes law. When the plan is thus approved, the process is reversed and the plan is subdivided as it passes back through the ministries, the industrial centrals, and the individual productive units. Thus every level of the economic system receives its instructions for the next period. ${ }^{162}$

Apparently the most important component of the Romanian foreign trade plan is the special plan for exports. Each economic unit has its own export plan established on both a quantitative and qualitative basis for each type of product. For each commodity there is a schedule according to the character of the destination country. These are usually divided into categories of (I) East-socialist countries; (2) West-free enterprise developed countries; or (3) West-free enterprise developing countries. ${ }^{153}$

According to article 29 of the foreign trade law, each import or export transaction requires a license from the Ministry of Foreign Trade. Instructions issued by the Ministry in the order of February 5, 1970, allow the cancellation or postponement of a license ( $\mathrm{I}$ ) if the export plan has been modified, (2) when the transaction does not fulfill the plan, (3) when the Romanian balance of payments will not permit trade with certain countries, or (4) when the economic unit involved has failed to act in accordance with its plan or the terms of the license. ${ }^{154}$

Obviously, under such rules Romanian contracts with foreign partners seem always to be concluded under a de jure protestative condition, which, beside its illegality, constitutes a permanent menace to the security and stability of the foreign partners' transactions. Therefore, to establish the confidence necessary for foreign trade, such provisions must be repealed.

\section{VI}

\section{Foreign Trade Contracts and Arbitration}

Unlike Poland and Czechoslovakia, Romania has not yet adopted a code of international law. The law in effect today was enacted prior to World War I and contains few provisions concerning international contracts. Therefore, the only sources defining the treatment of foreign trade contracts by Romania are the decisions of the Romanian Foreign Trade Arbitration Commission. Unfortunately, these decisions are not officially published. Some of them are released, apparently

${ }^{102}$ Art. 8, law no. I of I97I, 197I C.H. No. I, at II6.

${ }^{153}$ Detesan, supra note 105, at 154, 204.

${ }^{154}$ Id. at 202-05. 
on a selective basis, to Romanian specialists who publish commentaries in domestic and foreign periodicals. Thus, as the sources are selective, this study may not present a wholly accurate picture of the treatment of Romanian foreign trade contracts.

It is a generally accepted rule of conflict of laws that the capacity of a legal entity to engage in foreign transactions is governed by the law under which it was incorporated (lex societatis). The Romanian arbitration practice, as well as the new foreign trade law, accepts this rule. According to Romanian law, the fact that a legal entity was established under Romanian law does not give it the right or capacity to engage in foreign trade transactions. Only those Romanian enterprises which are authorized by the Council of Ministers may engage in such activity. ${ }^{155}$ Moreover, the law provides that in case of "main" contracts for the export or import of complex installations or equipment, only the general manager of the organization can sign the contract. ${ }^{156}$ Since the words "main export-import contracts" are used broadly by the law, the foreign partner should check this point each time he enters into this type of contract.

Article 2 of the Romanian Civil Code of 1864 adopts the locus regit actum conflicts rule. In theory this would mean that Romania would recognize a contract executed in a foreign country as formally valid if it would be formally valid under the law of the nation in which the contract was executed. In practice, however, Romanian foreign trade law requires compliance with Romanian provisions governing the form of contracts. The same rule is applied to the form of arbitration agreer ments, if the Romanian Foreign Trade Arbitration Commission is chosen as arbitrator. ${ }^{157}$ When the parties to the international trade contract include a provision in the contract selecting the law applicable in the settlement of disputes, Romanian arbitrators generally acquiesce. ${ }^{158}$

Romanian writers share the idea that the contractual freedom, generally recognized by all legislation, implies at the same time the right of parties to choose the law. ${ }^{159}$ But they think that this contractual freedom has certain limits, namely that "the exercise of rights and the performance of obligations resulting from the voluntary agreement of the parties will be admitted by the state only if the parties keep within the restraints imposed by it." ${ }^{\text {"60 }}$ Romania is a party to the European Convention on International Commercial Arbitration, which in article VII pro-

\footnotetext{
${ }^{105}$ Art. 2I, law no. I of I97I, I97I C.H. No. I, at $x 16$.

$200 \mathrm{Id}$. art. 7.

${ }^{157}$ Art. 2, decree no. 495 of 1953 , B.O. No. 49, Nov. 26, r953 (approving rules concerning the organization and working of the Arbitration Commission of the Chamber of Commerce of the Romanian People's Republic).

${ }^{168}$ Nestor \& Capatina, Chronique de jurisprudence roumaine, 95 JoURNaL DU DroIr INTERNATIONAL (Clunet) 438 (I968).

${ }^{200}$ Capatina, Conflicts of Laws Concerning the International Contracts of Sale of Commodities, 28 Revista Romana de Drext No. 3, at 20 (I972).

${ }^{100}$ Ionascu \& Nestor, The Limits of Party Autonomy-I, in The Sources of the Law of InternaTIONAL TRADE I84 (C. Schmitthoff ed. 1964 ).
} 
vides that "the parties shall be free to determine, by agreement, the law to be applied by the arbitrators to the substance of the dispute ...."161

When the parties do not specify the law which will govern the contracts in case of litigation, the practice of the Romanian Foreign Trade Arbitration Commission is to apply either the rule of lex loci contractus or lex loci executionis contractus. These two rules of conflict of laws are applied not because they express the implicit intention of the contracting partners but as rules of law. ${ }^{162}$ Whenever possible, the Arbitration Commission attempts to use locus regit actum, considered as "the main connecting factor in matters of international sale of goods."163

In disputes concerning contracts concluded by mail or telegram by parties in different countries, the Arbitration Commission uses the law of the nation where the contract was first formed. This occurs, according to the Commission, at the moment when the offeror receives notification of full acceptance of its offer from the offeree. Thus the residence of the offeror will be used to select the governing law. This practice leads to a true conflict of laws when the offeror country utilizes the so-called mailbox rule for the determination of the time of formation of a contract.

The Arbitration Commission has established an exception to the rule that a contract is formed when the offeror receives the offeree's full acceptance. This occurs when the offeree, without notifying the offeror of its acceptance of the offer, begins to fulfill the obligations provided in the written offer. In a 1956 case between a New York firm offering to buy Romanian caviar and a Romanian enterprise which carried out the provisions of the offer without notifying the New York firm of its acceptance, the Romanian Foreign Trade Arbitration Commission stated that:

The contract concluded between the parties provided for a quick execution, given the very short season when the caviar can be gathered. A previous answer of acceptance was not, thus, necessary, because it was replaced by the seller's execution of the contract. Consequently, according to Article 36 of the Commercial Code, the contract is governed by the dispositions of Romanian legislation. ${ }^{104}$

This award gives rise to at least one objection. If Romanian law provides that such contracts must be in written form, why did the Foreign Trade Arbitration Commission consider this case as an international contract of sale and why did it agree to arbitrate such an unwritten contract? Since the Romanian enterprise did not reply by letter or telegram to the offeror, it thus ignored the provision of its own law which does not recognize an international contract of sale unless it is in written form. Ian Nestor, who at that time was an arbitrator of the Romanian Foreign Trade Arbitration Commission, stated that

\footnotetext{
${ }^{101}$ European Convention on International Commercial Arbitration, Apr. 21, 1961, ${ }_{4} 84$ U.N.T.S. 349.

${ }^{102}$ Capatina, supra note 159, at 27.

${ }^{103} \mathrm{Id}$. at 28 .

${ }^{104} \mathrm{Id}$. at 30 .
} 
according to this law [the law applicable to foreign contracts], contracts concluded by economic organizations for foreign trade in the Romanian P.R. must not only be concluded by persons empowered to bind the contracting organizations, but must also-and this is to be underlined-be drawn up in writing. Consequently, the arbitration agreement must also be concluded in writing, this being a general requirement. ${ }^{165}$

If this is the law, what authorized the Arbitration Commission, in this case, to state that "a previous answer of acceptance was thus not necessary"? Has the Arbitration Commission the right to disregard its own law in this matter?

Beyond the "caviar case," there appears to be a conflict in the principles of Romanian law because article 28 of the foreign trade law of x971, reiterated the requirement that foreign trade contracts be in writing. If this is an absolute legal requirement, then the Foreign Trade Arbitration Commission should be bound thereby. If this is but a suggested approach, then foreign interests considering trade with Romania should be aware that the Arbitration Commission has at its disposal two alternative standards from which it may select at will, contrary to general ideas of justice.

\section{Concluston}

Romanian foreign trade has increased significantly since World War II. As with other socialist East European nations, this trade is directed by the central government, primarily through the use of long-range national plans covering all phases of the economy, including foreign trade. In addition to expanding trade by the use of traditional bilateral agreements, Romania has developed new organizational units, such as the industrial centrals, which are empowered to promote and expand foreign trade. Although some problems remain to be solved, the emphasis given foreign trade by the Romanian government and the general relaxation in East-West relations indicate a continued expansion of Romania foreign trade.

\footnotetext{
${ }^{106}$ Nestor, Arbitration Under the Authority of the Chamber of Commerce, in 3 UNION INTERNATIONALE des Avocats (International Commercial Arbitration-A World Handbook) 242-43 (P. Sanders ed. 1965$)$.
} 